\title{
Effect of Moringa olefiera on neurotoxicity induced by sodium fluoride in
}

\section{rats}

\author{
Abeer A.M. Shalan+1*, Shimaa A.El- Sayed², Gehad R. El-Sayed², El-Said E.EL-Said ${ }^{2}$ \\ ${ }^{1}$ Directorate of Veterinary Medicine, Mansoura 35511, Egypt. \\ ${ }^{2}$ Department of Biochemistry, Faculty of Veterinary Medicine, Mansoura University, Mansoura 35516, Egypt.
}

ARTICLE HISTORY
Received: 10.06 .2020
Revised: 20.06.2021
Accepted: 21.06.2021
Corresponding author: (Abeer Atef
Mahmoud Shalan) Tel: +201111578110
Email dr.abeershalan@yahoo.com;
Orcid https://orcid.org/0000-0002-1497-
7811
\begin{abstract}
Objective: This study was carried out to evaluate the detoxifying effects of aqueous extract of Moringa Oleifera on sodium fluoride-induced neurotoxicity in male Wister rats.

Design: Randomized controlled study.

Animals: Forty rats

Procedures: Rats were allocated into four equal groups (10 each). Basically, each group received the same basal diet for 30 days. The first group was not received additional treatment (negative control). However, the second group received $20 \mathrm{mg} / \mathrm{kg}$ b.wt sodium fluoride daily (positive control), the third group received sodium fluoride at a dose of $20 \mathrm{mg} / \mathrm{kg}$ b.wt and Moringa Oleifera at $300 \mathrm{mg} / \mathrm{kg}$ daily, and the fourth group received sodium fluoride at a dose of $20 \mathrm{mg} / \mathrm{kg} \mathrm{b.wt} \mathrm{and} \mathrm{Moringa} \mathrm{Oleifera} 500 \mathrm{mg} / \mathrm{kg}$ daily using a stomach tube.

Results: Dopamine and serotonin were significantly increased in Moringa Oleifera treated rats at 300 and $500 \mathrm{mg} / \mathrm{kg}$ in comparison with rats treated with sodium fluoride, but the higher dose of M. Oleifera achieved the best result $(1.23 \pm 0.13$ vs. $0.31 \pm 0.013)$ and $(2.95 \pm 0.019$ vs. $0.91 \pm 0.016)$ respectively. TAC, SOD, catalase were significantly increased in Moringa Oleifera treated rats at 300 and $500 \mathrm{mg} / \mathrm{kg}$ in comparison with rats treated with sodium fluoride, versed with MDA significantly decreased in Moringa Oleifera treated rats Also, to improve the anatomical structure of the disease in the brain reduces heavy bleeding and neurodegenerative changes, and maintains normal nerve cells, improves antioxidant ability as a whole. Conclusion and clinical relevance: Collectively, our results indicate that Moringa Oleifera watery extract has a detoxifying effect on $\mathrm{NaF}$ induced neurotoxicity via improving neurotransmitters andantioxidant activity.
\end{abstract}

Keywords: Sodium fluoride, Moringa Oleifera, rat, neurotoxicity.

\section{INTRODUCTION}

The toxicity of nervous system can be caused by several neurotoxins which is either naturally or manufactural produced and cause changes in the function of neuron neurotoxicity arises from exposure to substances used in radiation treatment, drug therapies, heavy metals, chemotherapy, as well as exposure to certain foods and food additivespesticides, certain drug abuse, industrial and/or cleaning solvents, and cosmetics[1].

Fluoride exposure can come from drinking water, food, toothpaste, mouthwash, and other dental products; Medicines, fluoride powder and fumes from industries that use fluorinecontaining salt and/or hydrofluoric acid lead to the release of superior anion oxide (O2-), [2] the overproduction of $\mathrm{O} 2$ and the consequences of its products such as hydrogen peroxide, peroxynitrite and hydroxyl radicals that are important for improving toxic effects Fluorine due to the accumulation of its products, [3].Experimental tests have indicated that exposure to fluorine causes oxidative stress either in the laboratory or in vivo in soft tissues such as the liver, kidneys, brain, lungs, and testes [4]. Fluorine inhibits the activities of the superoxide dismutase, glutathione Peroxidase;catalaseand reduces glutathione levels that leadto excessive production of reactive oxygen at the mitochondrial level, with the consequent damage to cellular components. Moreover, the production of excessive reactive oxygen species causes oxidation of large molecules, rupture of phospholipids, lipid peroxidation, depolarization of the mitochondrial membrane, and cell apoptosis [4] Therefore, an urgent request is required to reduce the toxic effects of fluoride. Unfortunately, potential medications to treat most brain diseases are often unable to cross brain barriers, and even those that can cross these barriers may be disrupted by many metabolic pathways. The search for new drug treatment from medicinal plants for neurotoxic diseases has progressed significantly over the past decade [5].In traditional medicine, many plants have been used to treat cognitive disorders. Natural products play an essential role in the prevention and treatment of various neurodegenerative diseases and neurological disorders. Anti-inflammatory and antioxidant 
activities of isolated plants and components are plants that have been used to improve neuritis, anxiety, and spasm [6].

Moringa Oleifera has been reported as an anti-cancer, antiinflammatory, thyroid condition, antioxidant, antimicrobial, cardiovascular, liver, anti-ulcer, diuretic, anti-urinary, and Anthelmintic properties [7].Some researchers have also reported possible hypoglycemia of Moringa Oleifera leaves [8]. Moringa can also be used as one of the strong nerves. Cerebral ischemia is caused by a blockage of blood flow to the brain. This leads to a re-pumping of oxidation and excretion of fatty oxidation, which in turn causes reactive oxygen species. Moringa with antioxidants can reduce reactive oxygen species, thereby protecting the brain [9]. Therefore, the current study was conducted to assess the potential protective role of Moringa Oleifera in rats exposed to the neurotoxicity of sodium fluoride by identifying neurotransmitter activities, antioxidant status, and tissue screening.

\section{MATERIALS AND METHODS}

\subsection{Rats}

In this study, 40 male Wister rats (130-180 g) were obtained from the Nile Institute (Mansoura, Egypt). Rats were kept in standard laboratory conditions in an air-conditioned room located in stainless steel cages, one for each cage at a temperature of $22 \pm 3^{\circ} \mathrm{C}$ and relative humidity of $30-70 \%$. The animal diet was managed adlibitum. The animals were acclimated for two weeks before the experiment.

\subsection{Sodium Fluoride}

Sodium fluoride (NaF) was purchased from Sigma Chemicals, St. Louis, Missouri, USA. The stock solution was prepared by dissolving $100 \mathrm{~g}$ of $\mathrm{NaF}$ in $1000 \mathrm{ml}$ of distilled water. The dosage schedule was so appropriate that the amount of $\mathrm{NaF}$ administration per animal depended on their weight.

\subsection{Moringa Olefiera}

Moringa Oleiferapapers were brought from the local market, Mansoura, Egypt. (10 g of leaves were ground and homogenized with $60 \mathrm{ml}$ of distilled water in the electric mixer. Then a decoction was filtered through sterile gauze. The transparent filter was stored in the refrigerator at $4^{\circ} \mathrm{C}$ and served from the raw extract broth the weight of the extract was expressed as the weight of the Moringa Oleiferaleaves that produced a quantity of the raw extract was the final concentration of the extract $(200 \mathrm{mg} / \mathrm{ml})$ [9].

\subsection{Preparation of diets and experimental design}

Diet formulation was performed in this study according to NRC (Tables 1 and 2). Rats were kept in stainless steel cages in hygienic conditions and fed for two weeks on a basal diet (BD) to adapt and supplied with adlibitum water. After a period of adaptation to the basaldiet, the rats were divided into 4 groups; Four diets were formulated first one contains basal diet as control (negative control), second one contain basal diet supplemented with $20 \mathrm{mg} / \mathrm{kg}$ b.wt sodium fluoride (positive control) [10], and the third one contains basal diet supplemented with $20 \mathrm{mg} / \mathrm{kg}$ b.wt + Moringa Oleifera 300 $\mathrm{mg} / \mathrm{kg}$, and fourth one contain basal diet supplemented with 20 $\mathrm{mg} / \mathrm{kg}$ b.wt + Moringa Oleifera $500 \mathrm{mg} / \mathrm{kg}$ using stomach tube and fed to rats daily for 30days [10].

Table 1. The food ingredients for every 100 kilograms of rat diet.

$\begin{array}{ll}\text { For each } 100 \mathrm{~kg} & \\ & \\ \text { Food ingredients } & \text { Number of kilograms } \\ \text { 1)Crushed Yellow Corn } & 40 \mathrm{~kg} \\ \text { 2)Wheat Flour } & 25 \mathrm{~kg} \\ \text { 3)Soya bean meal } & 8 \mathrm{~kg} \\ \text { 4)Milk powder } & 7 \mathrm{~kg} \\ \text { 5)Wheat bran } & 8 \mathrm{~kg} \\ \text { 6)Crushed Hay } & 10 \mathrm{~kg} \\ \text { 7)Mineral and vitamins premix } & 250 \mathrm{~g} \\ \text { 8)Salt } & 875 \mathrm{~g} \\ \text { 9) Lime stone } & 875 \mathrm{~g}\end{array}$

Table 2. The diet formulation according to NRC.

$\begin{array}{ll}\text { Nutrient } & \text { Amount } / \mathrm{kg} \text { die } \\ \text { Protein } & 150 \mathrm{~g} / \mathrm{kg} \\ \text { Fat } & 50 \mathrm{~g} / \mathrm{kg} \\ \text { Energy } & 3800-4100 \mathrm{kcal} / \mathrm{kg} \\ \end{array}$

\subsection{Sample collection}

At the end of the experiment, the animals have fasted overnight, and then theywereanesthetizedusing cotton swap saturated by Isoflurane up to $5 \%$ for induction under flask [11] and sacrificed to obtain blood samples direct from the heart. Blood and brain tissue samples were collected 30 days after the start of the experiment.

\subsection{Blood Samples}

Each blood sample is divided into two parts; each blood sample is divided into two parts; the first blood sample was collected on $10 \% \mathrm{Na-EDTA}$ tubes for conducting a complete blood count using Hematology Analyzer 3 Part Bc-2800 Single Chamber Hematology Analyzer. and the second blood was collected on a clean and sterile tube that was centrifuged at 3000rpm for 15 minutes for serum separation for determining the concentrations of serum total cholesterol (TC)[12], serum triacylglycerol (TAG)[13], serum high-density lipoproteincholesterol (HDL-c)[12], serum low-density lipoproteincholesterol (LDL-c)[13], serum total antioxidant capacity (TAC)[14], serum malondialdehyde [16], as well as the activities 
of serum superoxide dismutase (SOD)[15] and serum catalase[17]measured at $634 \mathrm{~nm}$ using a spectrophotometer.

\subsection{Tissue Sampling}

Brain divided into two parts;Brain divided into two parts; the first part of brain tissues was stored in $10 \%$ formalin for histopathological examination according to Woods [18], while the second part was stored at $2-8{ }^{\circ} \mathrm{C}$ for determination of serotonin and dopamine. Melt the samplethen add a certain amount of PBS (PH 7.4) and carefully homogenize the sample by hand or mixer. Centrifuge (at 2000-3000 rpm) for approximately 20 minutes. Carefully collect floating materials. Aliquot and keep one for examination and freeze others for later use to determine dopamine and serotonin [19] [20].

\subsection{Statistical analysis}

Results were reported to mean \pm SEM *. Statistical analysis was performed using the Shapiro-Wilk test to assess the normality of data, unidirectional ANOVA *, and the Pearson correlation coefficient. Values were considered significant $<0.05$. SPSS version 19 was used [21].

\section{RESULTS}

\subsection{Effect of Moringa Oleifera water extract on $C B C$ parameters}

Supplementation of Moringa Oleifera water extracts significantly increased $\mathrm{Hb}, \mathrm{RBCs}, \mathrm{WBCs}$, and PCV levels as compared to group 2 treated with $\mathrm{NaF}$ (Table. 3 ).

Table 3. Effect of Moringa Oleifera watery extract on CBC parameters at 30 days post-treatment.

\begin{tabular}{|c|c|c|c|c|c|c|}
\hline & $\begin{array}{l}\text { RBCs(* } \\
1012 / L)\end{array}$ & $\mathrm{Hb}(\mathrm{g} / \mathrm{L})$ & PCV (\%) & $\begin{array}{l}\text { WBCs } \\
(* 109 / L)\end{array}$ & $\begin{array}{l}\text { Neutrop } \\
\text { hils }\end{array}$ & $\begin{array}{l}\text { Lympho } \\
\text {-cytes }\end{array}$ \\
\hline $\begin{array}{l}\text { G1(negati } \\
\text { ve control) }\end{array}$ & $\begin{array}{l}7.17 \pm 0 \\
051^{\text {ab }}\end{array}$ & $\begin{array}{l}12.5 \\
\pm 0.10^{\mathrm{a}}\end{array}$ & $\begin{array}{l}12.31 \\
\pm 0.062^{\mathrm{a}}\end{array}$ & $\begin{array}{l}37.09 \\
\pm 0.027^{b}\end{array}$ & $\begin{array}{l}39.67 \\
\pm 26.27^{\mathrm{a}}\end{array}$ & $\begin{array}{l}70.33 \\
\pm 1.53^{b}\end{array}$ \\
\hline $\begin{array}{l}\text { G2(NaF20 } \\
\mathrm{mg} / \mathrm{kg} \text { ) }\end{array}$ & $\begin{array}{l}6.63 \pm 0 \\
066^{c}\end{array}$ & $\begin{array}{l}11.6 \\
\pm 0.07^{b}\end{array}$ & $\begin{array}{l}9.74 \\
\pm 0.04^{d}\end{array}$ & $\begin{array}{l}34.47 \\
\pm 0.078^{b}\end{array}$ & $\begin{array}{l}20.67 \\
\pm 6.42^{\mathrm{a}}\end{array}$ & $\begin{array}{l}59.00 \\
\pm 26.06^{b}\end{array}$ \\
\hline $\begin{array}{l}\text { G3(NaF } \\
20 \mathrm{mg} / \mathrm{kg}+ \\
300 \\
\mathrm{mg} / \mathrm{kgM} .0\end{array}$ & $\begin{array}{l}7.03 \pm 0 . \\
036^{b}\end{array}$ & $\begin{array}{l}11.7 \\
0.12^{b}\end{array} \quad \pm$ & $\begin{array}{l}11.54 \\
\pm 0.054^{c}\end{array}$ & $\begin{array}{l}36.71 \\
\pm 0.045^{b}\end{array}$ & $\begin{array}{l}22.00 \\
\pm 8.00^{\mathrm{b}}\end{array}$ & $\begin{array}{l}76.67 \\
\pm 5.77^{c}\end{array}$ \\
\hline $\begin{array}{l}\text { G4(NaF20 } \\
\mathrm{mg} / \mathrm{kg} \\
+500 \mathrm{mg} / \mathrm{k} \\
\mathrm{gM} .0 \text { ) }\end{array}$ & $\begin{array}{l}7.28 \pm 0 \\
077^{a}\end{array}$ & $\begin{array}{l}12.6 \\
\pm 0.09^{b}\end{array}$ & $\begin{array}{l}11.76 \\
\pm 0.056^{b}\end{array}$ & $\begin{array}{l}70.82 \\
\pm 3.68^{a}\end{array}$ & $\begin{array}{l}28.67 \\
\pm 3.21^{\mathrm{a}}\end{array}$ & $\begin{array}{l}76.00 \\
\pm 7.55^{c}\end{array}$ \\
\hline
\end{tabular}

\subsection{Changes in the levels of lipid profile parameters in rats exposed to NaF induced neurotoxicity and supplemented with Moringa Oleifera water extract}

Moringa Oleifera decrease lipid profile parameters that increased due to NaF exposure (Table. 4).

\subsection{Effect ofMoringa Oleifera water extract on antioxidant activity.}

A marked increase in total antioxidant capacity, SOD, catalase with a decrease in MDA level in groups treated with Moringa Olefiera water extract (Table. 5).

Table 4. Levels of cholesterol, Triglyceride, High-density lipoprotein, and Low-density lipoprotein $(\mathrm{mmol} / \mathrm{L}$ ) in rats exposed to $\mathrm{NaF}$ induced neurotoxicity and supplemented with Moringa Oleifera watery extract At at 30 days post-treatment.

\begin{tabular}{|c|c|c|c|c|}
\hline & $\begin{array}{l}\text { Choles- } \\
\text { terol }\end{array}$ & $\begin{array}{l}\text { Trigly- } \\
\text { ceride }\end{array}$ & $\begin{array}{l}\text { High- } \\
\text { density } \\
\text { lipoprotein }\end{array}$ & $\begin{array}{l}\text { Low-density } \\
\text { lipoprotein }\end{array}$ \\
\hline $\begin{array}{l}\text { G1(negative } \\
\text { control) }\end{array}$ & $\begin{array}{l}65.45 \\
\pm 5.34^{\mathrm{a}}\end{array}$ & $\begin{array}{l}94 \\
\pm 2.25^{b}\end{array}$ & $\begin{array}{l}33.15 \\
\pm 4.86^{\mathrm{b}}\end{array}$ & $\begin{array}{l}105.85 \\
\pm 3.07^{\mathrm{b}}\end{array}$ \\
\hline G2(NaF20mg/kg) & $\begin{array}{l}67.15 \\
\pm 2.99^{b}\end{array}$ & $\begin{array}{l}115 \\
\pm 3.62^{\mathrm{a}}\end{array}$ & $\begin{array}{l}50.45 \\
\pm 7.08^{\mathrm{a}}\end{array}$ & $\begin{array}{l}10.65 \\
\pm 2.44^{b}\end{array}$ \\
\hline $\begin{array}{l}\text { G3(NaF } \\
20 \mathrm{mg} / \mathrm{kg}+300 \\
\mathrm{mg} / \mathrm{kgM} .0 \text { ) }\end{array}$ & $\begin{array}{l}63.7 \\
\pm 2.047^{c}\end{array}$ & $\begin{array}{l}72 \\
\pm 2.561^{\mathrm{c}}\end{array}$ & $\begin{array}{l}43 \\
\pm 2.72^{b}\end{array}$ & $\begin{array}{l}30.3 \\
\pm 2.55^{b}\end{array}$ \\
\hline $\begin{array}{l}\mathrm{G} 4(\mathrm{NaF} 20 \mathrm{mg} / \mathrm{kg} \\
+500 \mathrm{mg} / \mathrm{kgM} . \mathrm{O})\end{array}$ & $\begin{array}{l}62 \\
\pm 2.278 c\end{array}$ & $\begin{array}{l}71 \\
\pm 3.443^{b}\end{array}$ & $\begin{array}{l}36.15 \\
\pm 3.6^{b}\end{array}$ & $\begin{array}{l}26.35 \\
\pm 4.17^{\mathrm{a}}\end{array}$ \\
\hline
\end{tabular}

Results were expressed as mean with its standard error of the mean. In each column, the means carried similar letter showed a non-significant change

Table 5. Effect of Moringa Oleifera watery extract on antioxidant activity and oxidative stress markers in rats exposed to $\mathrm{NaF}$ induced neurotoxicity.

\begin{tabular}{|c|c|c|c|c|}
\hline & $\begin{array}{l}\text { Total } \\
\text { antioxidant } \\
\text { capacity(mM/L) }\end{array}$ & $\begin{array}{l}\text { SOD } \\
(\mathrm{u} / \mathrm{mL})\end{array}$ & $\begin{array}{l}\text { MDA } \\
(\mathrm{nmol} / \mathrm{mL})\end{array}$ & $\begin{array}{l}\text { Catalase } \\
(U / L)\end{array}$ \\
\hline $\begin{array}{l}\text { G1(negative } \\
\text { control) }\end{array}$ & $\begin{array}{l}0.659 \\
\pm 33.83^{b}\end{array}$ & $\begin{array}{l}89.1 \\
\pm 2.25^{b}\end{array}$ & $\begin{array}{l}3.43 \\
\pm 0.23^{b}\end{array}$ & $\begin{array}{l}354 \\
\pm 0.07^{b}\end{array}$ \\
\hline G2(NaF $20 \mathrm{mg} / \mathrm{kg}$ ) & $\begin{array}{l}0.624 \\
\pm 28.16^{a}\end{array}$ & $\begin{array}{l}64.31 \\
\pm 2.6^{b}\end{array}$ & $\begin{array}{l}6.19 \\
\pm 0.35^{\mathrm{a}}\end{array}$ & $\begin{array}{l}603 \\
\pm 0.02^{b}\end{array}$ \\
\hline $\begin{array}{l}\text { G3(NaF20mg/kg+ } \\
300 \text { mg/kgM.O) }\end{array}$ & $\begin{array}{l}0.693 \\
\pm 13.19^{\mathrm{a}}\end{array}$ & $\begin{array}{l}169.6 \\
\pm 11.13^{\mathrm{a}}\end{array}$ & $\begin{array}{l}3.08 \\
\pm 0.12^{b}\end{array}$ & $\begin{array}{l}616.5 \\
\pm 0.006^{b}\end{array}$ \\
\hline $\begin{array}{l}\text { G4(NaF } \\
20 \mathrm{mg} / \mathrm{kg}+500 \mathrm{mg} / \\
\mathrm{kgM} . \mathrm{O})\end{array}$ & $0.695 \pm 4.98^{\mathrm{a}}$ & $\begin{array}{l}163.55 \\
\pm 12.57^{\mathrm{a}}\end{array}$ & $\begin{array}{l}3.44 \pm 0.0 \\
9^{b}\end{array}$ & $603 \pm 0.1^{a}$ \\
\hline
\end{tabular}

Results were expressed as mean with its standard error of the mean. In each column, the means carried similar letter showed a non-significant change

\subsection{Effect of Moringa Oleifera water extracts on neurotransmitters levels}

Moringa Olefiera water extract improves neurotransmitters (dopamine and serotonin) levels when compared with $\mathrm{NaF}$ treated group (Table. 6).

\subsection{Histopathologicalexamination}

Brain tissue of G2 is showing neuronal necrosis (arrow). While brain tissue of G3 showing chromatolysis (arrow) and normal blood capillaries (arrowhead).Brain tissue of the G4 brain is showing normal neurons (arrow) and normal blood capillaries (arrowhead). Figures 1 A, B, C, and D respectively. 
Table 6.Effect of Moringa Oleifera watery extracts on neurotransmitters levelat 30 days post-treatment.

\begin{tabular}{|c|c|c|}
\hline & $\begin{array}{l}\text { Dopamine }(\mu \mathrm{g} / 100 \mathrm{~g} \\
\text { tissue) }\end{array}$ & $\begin{array}{l}\text { Serotonin } \\
\text { tissue) }\end{array}$ \\
\hline $\begin{array}{l}\text { G1 (negative } \\
\text { control) }\end{array}$ & $2.21 \pm 0.062^{\mathrm{a}}$ & $3.19 \pm 0.042^{\mathrm{a}}$ \\
\hline G2(NaF2Omg/kg) & $0.31 \pm 0.013^{d}$ & $0.91 \pm 0.016^{d}$ \\
\hline $\begin{array}{l}\text { G3 (NaF 20mg/kg+ } \\
300 \text { mg/kgM.O) }\end{array}$ & $0.84 \pm 0.097^{c}$ & $1.86 \pm 0.043^{c}$ \\
\hline $\begin{array}{l}\text { G4 (NaF 20mg/kg } \\
+500 \mathrm{mg} / \mathrm{kgM} . \mathrm{O})\end{array}$ & $1.23 \pm 0.13^{b}$ & $2.95 \pm 0.019^{b}$ \\
\hline
\end{tabular}

Results were expressed as mean with its standard error of the mean. In each column, the means carried similar letters showed a non-significant change.
(A)

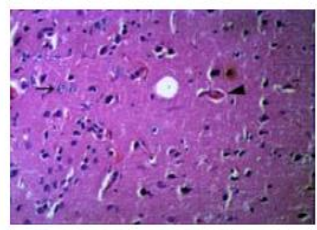

(C)

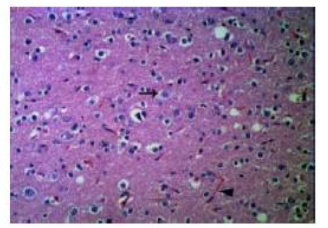

(B)

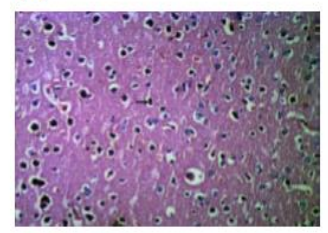

(D)

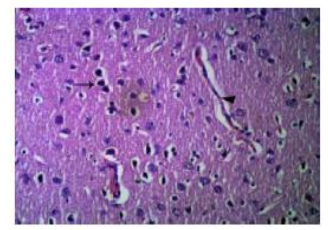

Fig .1

Fig 1 Histopathologicalexamination of brain tissues of rats exposed to Nafl induced neurotoxicity and supplemented with Moringa Oleifera water extract(A) Brain tissue of group 1, (B) Brain tissue of group 2 neurodegenerative changes Some pyramidal neurons showed chromatolysis and were shrunken with vacuolation around them, The nuclei of some pyramidal neurons was eccentric in neuroplastic andother wereshowing necrosis. Some granule cells were swollen in shape and size. At some location, neuropil exhibited heterogeneous acidophilic masses containing fragments of nuclei and clear halos.(C) Brain tissue of group 3release to degeneration and (D) Brain tissue of group 4 normal cells. (HE, 100x).

\section{DISCUSSION}

A model for stimulating neurotoxicity in animals is the administration of sodium fluoride as described in [22]. In the present study, the administration of $\mathrm{NaF}$ caused an increase in total lipids, cholesterol, triglycerides, HDL, Causing a decrease in TAC, MDA, catalase, and SOD compared to the control group. A significant return to normal occurred after the M.O. Leaves watery extract was given at a dose of $500 \mathrm{mg}$ more than a dose of $300 \mathrm{mg}$. This improvement may be because M.O. is the fat reducing agent while the increase in the level of antioxidants can be attributed to Moringa's antioxidant activity. M.O.indicated its hypolipidaemic activity as its leaves are a good source of phytochemicals including flavonoids, phenols, and carotenoids; $\beta$-sitosterol that has a similar structure to cholesterol structure, except for cholesterol substitution [23]. Ethyl C24 group of its side chain. It was believed that this compound could lower cholesterol by lowering plasma LDL-C concentrations. Therefore, $\beta$-sitosterol in M.O. leaves is a bioactive plant component representing the effect of hypolipidaemic from M.O. extract [23].Another possible reason is that $\beta$-sitosterol may reduce the intestinal absorption of dietary cholesterol and may partially explain the plasma lower cholesterol and fecal cholesterol in rodents treated with M.O.leaves [24].

In this study, the antioxidant activity of Moringa leaves extract can be attributed to its phenolic content and related to the destruction of flavonoids isolated from this plant. It is consistent with many reports on flavonoids from the Moringaceae family which includes quercetin 3-Orhamnoglucoside and quercetin 3-O-glucoside in $M$. stenopetala, quercetin 3'-methoxylated, vitexin, quercetin 3-Oglucoside, quercetin 3-0-6 "-malonyl-glucoside and lower kaempferol quantities 3-0-glucoside and kaempferol 3-0- (6 "Malonyl-glucoside) in the leaves of M.O.and myricetin in the seeds of M.O.showed anti-oxidant activity [25]. The results showed that M.O. extracts can resist the formation of free radicals and other reactive species resulting from the state of the disease, thereby reducing oxidative stress and preventing the results of oxidative damage from aligning with the results obtained by Sreelatha [26] that reported that the M.O.plant was reported to prevent Structural changes and oxidative damage to the rat lens by improving enzymatic antioxidant activities, lowering the level of lipid peroxide and inhibiting the formation of free radicals or reactive typesofoxygen(ROS)[26].

In addition to the antioxidant effects, Moringa leaves have been found to have a nutritional value that helps improve overall health by maintaining blood parameters (volume of packed cells, number of white blood cells, and differentiation of white blood cells as cause increase in the level of lymphocyte count in all the test groups. hemoglobin and platelets) relieve iron deficiency anemia, which has also been reported It is positively affected by the use of this plant [27] This can be attributed to its content of essential vitamins such as vitamins A, complex B (which includes B1, B3, B6, and B7), C, D, E, and K.

On the other hand, treatment with $\mathrm{MO}$ increases the level of dopamine can have a protective action on dopaminergic neurons in the cortical and hippocampal regions, and thus can support the memory process [20]. The MO leaves extract can eventually work by stimulating adrenergic receptors in different areas of the brain. MO treatment showed an increase in beta wave frequency along with a significant decrease in the number 
of peak discharges indicating a role in improving coordinated and integrated brain function. MO leaf is a powerful source of antioxidants like vitamin $\mathrm{C}$ and $\mathrm{E}$ and other flavonoids, amino acids, alkaloids, and various other compounds, which can be a powerful memory enhancer [28].

Most of the 5-hydroxy tryptamine (5-HT) in the brain is located in the hypothalamus, the hypothalamus, the middle, and the fourth brain of the lower brain stem. There was growing evidence that the 5-HT system was important in regulating memory and could, therefore, be associated with attention deficit disorder while research results on this topic were inconsistent. Serotonin is associated with emotional behavior in rats [29]. Therefore, it can be assumed that anxiety in Alzheimer's disease may be associated with serotonin disorder activity. In our results, MO water extracts significantly increase serotonin levels and thus increase the 5-HT level. 5-HT shows an inhibitory action in the central nervous system. Consequently, a 5-HT reduction in DC could have increased the number of peak discharges [30]

Moringa Oleifera plant extract is also a powerful cofactor that reduces neurodegeneration in the brain of rats treated with $\mathrm{NaF}$ [29]. Our results were confirmed by pathological results that showed that the degenerative change of neutrophils and neurodegenerative changes observed in different areas of the brain (neocortex, hippocampus, cerebellum) (Figure 1B) were improved after treatment with MO since the brain pathological tissues of groups with The acute management of Moringa olefiera extracts has less neurological degeneration and neurons look normal as shown in (Figure 1.C).

\section{Conclusion}

In conclusion, our study suggested protective effectsin the treatment of neurotoxicity due to the direct impact on neurotransmitters, and the improvement of the entire blood profile has an important role as a factor of hypolipidemia (pure antioxidants).

\section{Conflict of interest}

Authors declare that they have no conflict of interest

\section{Acknowledgment}

This research was supported by the Laboratory of Biochemistry Department of biochemistry and chemistry of Nutrition, Faculty of Veterinary Medicine, Mansoura University.

\section{Research Ethics Committee Permission}

The current research work is permitted to be executed according to standards of Research Ethics committee, Faculty of Veterinary Medicine, Mansoura University.

\section{Authors 'contribution}

El-Said E.EL-Said designed the experiment and revised the manuscript. El-Said E.EL-Said, Gehad R. El- Sayed, Shimaa A. ElSayed supervised in carrying out the practical part. Abeer A.M. Shalan shared in writing the paper and took the responsibility of correspondence to the journal.

Abeer A.M. Shalan collected samples and carried out the practical part. All authors approved the final version of the manuscript for publication.

\section{REFERENCES}

[1] Costa LG, Giordano G, Guizzetti M, Vitalone A. Neurotoxicity of pesticides: a brief review. Front Biosci. 2008;13:1240-1249. https://doi.org/10.2741/2758

[2] Hamza R Z, AL-Harbi M S, Sodium fluoride induced neurotoxicity and possible antioxidant role of selenium and curcumin in male mice. Biosci. Biotechnol. Res. Asia, $2014 . \quad$ 11, 81-87. https://doi.org/10.13005/bbra/1236

[3] Ruiz P, Comprehensive textbook of psychiatry B. J. Sadock, \& V. A. Sadock (Eds.). Philadelphia, PA: lippincott Williams \& wilkins. 2000. Vol. 1, pp. 938950.

[4] Barbier O; Arreola-Mendoza L, Razo LMD, Molecular mechanisms of fluoride toxicity. ChemBiol Interact.2010. 188: 319-33. https://doi.org/10.1016/j.cbi.2010.07.011

[5] Suk K, Regulation of Neuroinflammation by Herbal Medicine and Its Implications for Neurodegenerative Diseases.Neurosignals. 2005; 14:2333. https://doi.org/10.1159/000085383

[6] Adams M, GmünderF, HamburgerM, Plants traditionally used in agerelated brain disorders a survey of ethno botanical literature. Journal of Ethno pharmacology. 2007; 113:363-381. https://doi.org/10.1016/j.jep.2007.07.016

[7] Farooq F, Rai M, Tiwari A, Khan AA, Farooq S. Medicinal properties of Moringa oleifera: An overview of promising healer. Journal of Medicinal Plants Research. 2012 Jul 18;6(27):4368-74. https://doi.org/10.5897/JMPR012.279

[8] Ajitkar-Choudhary B K, Bandyopadhyay N G, Comparative evaluation of the hypoglycemic activity of some Indian medicinal plants in alloxan diabetic rats. Journal of Ethno pharmacology 2003.84:105-108. https://doi.org/10.1016/S0378-8741(02)00144-7

[9] Adeyemi O S, Elebiyo T C, Moringa Oleifera supplemented diets pre-vented nickel-induced nephrotoxicity in Wistar rats, J. Nutr. Metab.2014.1-8. https://doi.org/10.1155/2014/958621

[10] Amardeep U, Kamble-Alka R, Sawarkar-Sonali D, Borkar C R, Jangde W, Effect of Moringa Oleifera Lam. on hematological and histopathological parameters in sodium fluoride-induced toxicity in Wister rats Annals of Phytomedicine 2017. 6: 57-62. https://doi.org/10.21276/ap.2017.6.1.8

[11] Hawkins M G, Guzman D S M, Paul-Murphy J., General Principles of Analgesia and Anesthesia in Wildlife. Medical Management of Wildlife Species: A Guide for Practitioners 2019. 45-73. https://doi.org/10.1002/9781119036708.ch5

[12] Allain CC, Poon LS, Chan CSG, Richmond W, Fu P C, Enzymatic determination of total serum cholesterol.Clinical Chemistry.1974. 470-475. https://doi.org/10.1093/clinchem/20.4.470

[13] Fossati P, Prencipe L. Serum triglycerides determined colorimetrically with an enzyme that produces hydrogen peroxide. Clin Chem. 1982; 28(10):2077-2080. https://doi.org/10.1093/clinchem/28.10.2077

[14] Kovacevic D, Kovacevic G, Djordjevic V, et al. Method for the measurement of antioxidant activity in the human fluid. Journal of Clinical Pathology 2001, 54, 356-361. https://doi.org/10.1136/jcp.54.5.356

[15] Nishikimi M, Appaji-Rao N, Yagi K, The occurrence of superoxide anion in the reaction of reduced phenazinemeth sulfate andmolecular oxygen. Biochemical and Biophysical Research Communications 1972; 849-854. https://doi.org/10.1016/S0006-291X(72)80218-3 
[16] Esterbauer H, Cheeseman K H, Determination of aldehydic lipid peroxidation products: malonaldehyde and 4-hydroxynonenal. Methods Enzymol. 1990;186:407-421. https://doi.org/10.1016/00766879(90)86134-H

[17] Aebi H, Bergmeyer H U, Methods of enzymatic analysis. Catalase., Volume 2 reviews developments in the determination of enzyme activity Methods Enzymol 1984. 105, 121-126.

[18] Woods A E, (Ed.). Laboratory histopathology: a complete reference.vol 1 Churchill Livingstone.1994,38-124

[19] Ciprandi G, Amici M, Tosca M, Alesina R, Marseglia G, Fuchs D, Serotonin in allergic rhinitis: a possible role for behavioral symptoms. Iranian Journal of Allergy, Asthma and Immunology2011, 183-188.

[20] Ganguly R, Guha D, Alteration of brain monoamines \& EEG wave pattern in a rat model of Alzheimer's disease \& protection by Moringa Oleifera. Indian Journal of medical research, 2008. 128(6).

[21] Maximova S, Noyanzina O, Omelchenko D, multinationalism, Russian mentality and natives' attitudes towards immigrants: evidence from survey experiments across borderland regions of Russia. Economic and Social Development: Book of Proceedings, 2017. 1-14.

[22] Kamble A U, Sawarkar A R, Borkar S D, Jangde C R. Effect of Moringa oleifera Lam. on hematological and histopathological parameters in sodium fluoride-induced toxicity in Wister rats. Annals of Phytomedicine-an international journal 2017; 6: 57-62. https://doi.org/10.21276/ap.2017.6.1.8

[23] Ahmed H, Metwally M, Rashad H, Zaazaa M, Ezzat M, Salama M, Moringa oleifera offers a multi-mechanistic approach for management of obesity in rats 2014 Int. J. Pharm. Sci. Rev. Res., 29(2), Article No. 19, Pages: 98-106.

[24] Mbikay M , Therapeutic potential of Moringa oleifera leaves in chronic hyperglycemia and dyslipidemia: a review. Frontiers in pharmacology 2012, 3, 24. https://doi.org/10.3389/fphar.2012.00024

[25] Dehshahri S H, Wink M, Afsharypuor S, Asghari G, MohagheghzadehA, Antioxidant activity of methanolic leaf extract of Moringa peregrina (Forssk.) Fiori. Research in pharmaceutical sciences,2012. 7(2), 111.

[26] Sreelatha S, Padma P R, .Antioxidant Activity, and Total Phenolic Content of Moringa Oleifera Leaves in Two Stages of Maturity,PlantFoods Hum Nutr, 2009. 64, 303-311. https://doi.org/10.1007/s11130-009-0141-0

[27] Adedapo A A, Mogbojuri O M, Emikpe B O, Safety evaluation of the aqueous extract of the leaves of Moringa Oleifera in rats. Journal of Med. plants Res 3 (2009): 586-591.

[28] Daberkow D P, Kesner R P, Keefe KA, Relation between methamphetamine-induced monoamine depletions in the striatum, and sequential motor learning. Pharmacol Biochem Behav 2005; 81: 198-204. https://doi.org/10.1016/j.pbb.2005.03.010

[29] Ha TM, Cho DM, Park SW, Joo MJ, Lee BJ, Kong BG, et al, Evaluating associations between 5-HTTLPR polymorphism and Alzheimer's disease for Korean patients. Dement GeriatrCognDisord 2005; 20: 31-4. https://doi.org/10.1159/000085071

[30] AremuA, Kingsley E I, Talha BK, Akeem AO, Ibrahim R A, Jimoh A G, Yusuf S $\mathrm{K}$, Methanolic leaf extract of Moringa oleifera improves the survivability rate, weight gain and histopathological changes of Wister rats infected with Trypanosoma brucei. International Journal of veterinary science and medicine, 2018; 6: 39-44. https://doi.org/10.1016/j.ijvsm.2018.04.006 